\title{
Maria Skłodowska-Curie i Ernest Rutherford - przyjaźń, współpraca i rywalizacja
}

\section{Maria Skłodowska-Curie and Ernest Rutherford - Friendship, Collaboration and Rivalry}

For the first quarter of the $20^{\text {th }}$ century, the Curie Laboratory and the Ernest Rutherford Laboratory were the two main research centers for radioactivity. Both dealt with the same field, but had different priorities from the beginning. The Paris laboratory focused on discovering and studying the properties of new radioactive elements, while Rutherford in his laboratories in Montreal, and later in Manchester and Cambridge, tried, above all, to explain the very nature of radioactivity. There was a clear competition between the two laboratories, which, however, did not preclude personal and scholarly cooperation between their heads of research, i.e. Maria Skłodowska-Curie and Ernest Rutherford.

The article discusses the main topics of this collaboration, such as developing a radium template, assigning scientific terminology, organizing scientific conferences, and preparing students. In addition, a few passages were devoted to the private relations between both scientists, which had a direct impact on their collaboration.

Keywords: Maria Skłodowska-Curie, Ernest Rutherford, radioactivity, research, collaboration, friendship, rivalry

Słowa kluczowe: Maria Skłodowska-Curie, Ernest Rutherford, promieniotwórczość, badania naukowe, współpraca, przyjaźń, rywalizacja

Przez pierwszą ćwierć XX w. Laboratorium Curie oraz Laboratorium Ernesta Rutherforda1 uznawane były za dwa główne ośrodki badań nad promieniotwórczością.

Obydwa zajmowały się tą samą dziedziną, jednak od początku miały inne priorytety. Paryskie laboratorium państwa Curie koncentrowało się na odkrywaniu i badaniach wła-

1 Ernest Rutherford (1871-1937) - słynny fizyk brytyjski urodzony w Nowej Zelandii, w latach 1898-1907 profesor uniwersytetu w Montrealu, a w latach 1907-1919 w Manchesterze, od 1919 r. w Cambridge, gdzie kierował Cavendish Laboratory. Od 1922 r. członek Royal Society (od 1925 r. członek zagraniczny Polskiej Akademii Umiejętności). Twórca podstaw współczesnej nauki o promieniotwórczości i budowie atomu. Wykazał w 1899 r. odrębną naturę promieniowania $\alpha$ i $\beta$. W 1903 r. wspólnie z F. Soddym przedstawił teorię rozpadu promieniotwórczego. Za badania rozpadu promieniotwórczego pierwiastków otrzymał w 1908 r. Nagrodę Nobla z chemii. W 1911 r. odkrył jądro atomowe, a następnie stworzył planetarny model atomu. W 1914 r. wykazał falową naturę promieniowania $\gamma$. W 1919 r. przeprowadził pierwszą reakcję jądrową. Za swoje zasługi naukowe otrzymał tytuł lorda. 
ściwości nowych pierwiastków promieniotwórczych, podczas gdy Rutherford w swoich laboratoriach - w Montrealu, a następnie w Manchesterze i w Cambridge - starał się przede wszystkim wyjaśnić samą naturę promieniotwórczości.

Podobnie było w latach późniejszych, już po śmierci Piotra Curie w 1906 r., kiedy samodzielnym kierownikiem paryskiego laboratorium została jego żona - Maria. Największym osiągnięciem Laboratorium Curie stało się wtedy (w 1910 r.) uzyskanie metalicznego radu.

Pomiędzy obydwoma laboratoriami cały czas istniała wyraźna rywalizacja, co nie wykluczało jednak osobistej i merytorycznej współpracy oraz przyjaźni pomiędzy ich kierownikami.

W swoich wczesnych pracach Rutherford powoływał się przede wszystkim na osiągnięcia badaczy brytyjskich, zwłaszcza z kręgu własnego laboratorium. Spośród uczonych francuskich, obok Becquerela ${ }^{2}$, uwzględniał jednak (dość skromnie) badania Piotra i Marii ${ }^{3}$. Natomiast Maria Skłodowska-Curie zdecydowanie bardziej brała pod uwagę osiągnięcia Rutherforda, odnosząc się do jego badań w swoich pracach, m.in. w swoim wystąpieniu na uroczystości przyznania Nagrody Nobla - omawiając dzieje odkryć w zakresie promieniotwórczości, parokrotnie podkreśliła zasługi Rutherforda w tej dziedzinie ${ }^{4}$.

W 1910 r. ukazało się dwutomowe dzieło Skłodowskiej-Curie, zatytułowane Traité de radioactivité, podsumowujące całą ówczesną wiedzę na temat promieniotwórczości. Był to w gruncie rzeczy dopracowany redakcyjnie cykl wykładów, jakie Skłodowska-Curie miała na Sorbonie. Zdaniem Rutherforda, dzieło było "bardzo ciężkie i bardzo długie”, ale zawierało też „wiele użytecznych informacji zebranych razem”. Według niego, Skłodowska-Curie zrobiła błąd, próbując objąć zbyt wiele zagadnień, co wpłynęło na ich zbyt powierzchowne przedstawienie. Docenił natomiast wiedzę i szacunek, jakim darzyła osiągnięcia uczonych spoza Francji. „W każdym razie - pisał do B.B. Boltwooda, radiochemika z Uniwersytetu Yale ${ }^{5}$ - muszę przyznać, że nie zostałem pominięty". Czytając książkę, miał wrażenie jakby czytał własną (którą właśnie przygotowywał). Niektóre rozdziały zaczynały się prawie tak samo, a treść opracowania została podzielona w podobny sposób. „Myślę - pisał -że ona [M. Curie] jest lepsza, niż ktoś mógłby oczekiwać, w zakresie chemii, ale

2 Henri Becquerel (1852-1908) - fizyk i chemik francuski, od 1895 r. profesor i rektor École Polytechnique w Paryżu. W 1896 r. odkrył zjawisko promieniotwórczości, za co w 1903 r., wspólnie z małżonkami Curie, otrzymał Nagrodę Nobla.

3 M.in. w takich pracach jak: The New Gas from Radium (1901), Emanation from Radio-active Substances (1901), The Radioactivity of Thorium Compounds (1902), The Cause and Nature of Radioactivity (1902), A Comparative Study of the Radioactivity of Radium and Thorium (1903), The Succession of Changes in Radioactive Bodies (1904), Slow Transformation Products of Radium (1905), The Chemical Nature of the -Particles from Radioactive Substances (1908 - wykład noblowski). Zob. The Collected Papers of Lord Rutherford of Nelson, t. 1-2, London 1962-1963.

4 Tekst wystąpienia M. Curie za K. Blanc, Marie Curie et le Nobel, Uppsala 1999, s. 159-169. Rutherford, przesyłając gratulacje tuż po otrzymania przez Marię Nagrody Nobla, pisał m.in: „Jedynie parę dni temu mówiłem Langevinowi, że uważam, iż to Pani powinna otrzymać nagrodę i dodatkową przyjemność sprawia mi to, że komitet noblowski podzielał moje zdanie. [...] Jeszcze raz najgorętsze moje gratulacje i takież od Pani Rutherford". Bibliothéque Nationale [BN], NAF 18461, k. 332, list z 8.11.1911.

5 Bertram Borden Boltwood (1870-1927) - radiochemik amerykański, profesor na Uniwersytecie w Yale, przyjaciel i współpracownik Rutherforda. Posiadał duży dorobek naukowy, m.in. w 1906 r. wykazał, że niektórych pierwiastków nie da się od siebie oddzielić metodami chemicznymi. W 1906 r. odkrył jon - izotop toru 230. 
ujawnia braki w zakresie fizyki, co widać zwłaszcza w jej analizie promieniowania. Jest bardzo zabawne czytać fragmenty, w których przypisuje pierwszeństwo nauce francuskiej lub raczej sobie i swojemu mężowi". Podobnie protekcjonalnie kończył swoją ocenę książki: „Reasumując, uważam, że biedna kobieta się napracowała, a jej dwa tomy będą bardzo użyteczne jedynie przez rok lub dwa"6.

Rutherford postanowił w tej sytuacji nie spieszyć się z wydaniem własnej pracy o promieniotwórczości i ograniczyć ją do jednego, „sensownego” tomu”. Została ona wydana w 1913 r. pod tytułem Radioactive Substances and Their Radiations (Cambridge).

Niewykluczone, że wpływ na tak sformułowaną, ironiczną i protekcjonalną opinię Rutherforda na temat książki Skłodowskiej-Curie miała osoba adresata listu - Bertrama B. Boltwooda. Jak się wydaje, nie darzył on jej estymą od czasu, gdy doszło do zadrażnień w związku z jego krytyką pracy bliskiego współpracownika Skłodowskiej-Curie - André Debierna ${ }^{8}$. Obrażony Boltwood pisał wtedy do Rutherforda: „Szkoda, że pewni ludzie są tak bardzo wrażliwi na krytykę a Madame [M. Curie] najwidoczniej uważa, że każdy związany z jej laboratorium jest swego rodzaju świętym" ${ }^{\prime 9}$. W kolejnych listach do Rutherforda zawsze uszczypliwie wypowiadał się na jej temat, a w trakcie wizyty Skłodowskiej-Curie w USA w 1921 r. był przeciwny przyznaniu jej doktoratu honoris causa przez jego własny Uniwersytet ${ }^{10}$.

Do bliższych kontaktów między Skłodowską-Curie a Rutherfordem doszło przed Międzynarodowym Kongresem Radiologii i Elektryczności, który miał miejsce w Brukseli między 13 a 15 września 1910 r. Rutherford zwrócił się wtedy do niej z propozycją porównania swojego wzorca radowego ze wzorcem radowym znajdującym się w posiadaniu laboratorium paryskiego. W odpowiedzi z maja tegoż roku Skłodowską-Curie wyraziła zgodę, obiecując że wkrótce wyśle odpowiedni preparat. Nawiązała przy tym do faktu przeprowadzki Rutherforda z McGill Uniwersity w Kanadzie do Uniwersytetu w Manchesterze. „Teraz, kiedy mieszka Pan w Manchesterze - pisała - będziemy mieli przyjemność częściej widzieć Pana w Paryżu". Zapytywała czy uważa, że Kongres w Brukseli będzie interesujący i czy się na niego wybiera ${ }^{11}$.

W sierpniu 1910 r., a więc tuż przed Kongresem, pisała do Rutherforda, że podobnie jak on uważa możliwość porównywania wzorców radowych za bardzo ważną dla rozwoju nauki o promieniotwórczości. Zapowiadała, że przyjedzie na Kongres i wyrażała zgodę na projekt Rutherforda utworzenia w trakcie Kongresu komisji, która podjęłaby kwestię wzorca. Zastanawiała się, na jakich warunkach mogłaby podjąć się przygotowania takiego wzorca. Pisała, że o ile samo przygotowanie wzorca jest dla niej łatwe, o tyle trudność

6 Rutherford and Boltwood. Letters on Radioactivity, red. L. Badash, New Haven, London 1969, s. 234-235, list z 14.12.1910.

7 Ibid., s. 235, 244, list Rutherforda do Boltwooda z 1.02.1911.

8 André Debierne (1874-1949) - chemik i fizyk chemiczny, początkowo pracował w laboratorium chemii fizycznej, kierowanym przez Jeana Perrina na Sorbonie, a następnie, od 1896 r. z małżeństwem Curie. Od 1908 r. profesor Sorbony. W 1899 r. opracował przemysłowe sposoby przetwarzania pechblendy w celu wydzielenia radu. W październiku 1899 r. odkrył trzeci pierwiastek radioaktywny - aktyn. W 1910 r., wraz ze SkłodowskąCurie, wyizolował rad metaliczny. Po jej śmierci kierował Laboratorium Curie.

9 Rutherford and Boltwood. Letters on Radioactivity, s. 195-196, list z 11.09.1908.

10 Zob. ibid., s. 238, list z 11.01.1911, s. 260, list z 5.11.1911 lub s. 346, list z 14.07.1921.

11 Cambridge University Library [CUL], Add 7653, C 93-94, list z 19.05.1910, C 95-96, list z 29.06.1910. W liście z 29 czerwca donosiła, że wysyła ampułkę zawierającą około 2 mg chlorku radu i omawiała metodę jej przygotowania. 
sprawiać będzie zorganizowanie systemu pomiarów porównawczych i jego stosownej obsługi. Było dla niej oczywiste, że wzorzec będzie przechowywany w jej laboratorium. W składzie proponowanej przez Rutherforda międzynarodowej komisji postulowała parę zmian, m.in. żeby jako jednego z dwóch przedstawicieli Niemiec wprowadzić Ottona Hahna, co zostało przez Rutherforda zaakceptowane ${ }^{12}$.

Rutherford był głównym animatorem Kongresu i on odgrywał tam najważniejszą rolę. W trakcie obrad najwięcej uwagi poświęcono kwestii porównywalności pomiarów promieniotwórczości w różnych laboratoriach. Powołano komisję, co do której wcześniej Rutherford porozumiewał się ze Skłodowską-Curie. W jej skład ze strony Francji weszła oczywiście Skłodowska-Curie, a także André Debierne. Z Wielkiej Brytanii Ernest Rutherford i Frederick Soddy, z Niemiec Otto Hahn i Hans Geitel, z Austrii Stefan Meyer i Egon Schweidler, a ze Stanów Zjednoczonych Bertram B. Boltwood i Arthur S. Eve. Komisja uznała konieczność sporządzenia międzynarodowego wzorca radu i to zadanie powierzyła Skłodowskiej-Curie ${ }^{13}$.

Skłodowska-Curie i Rutherford po raz pierwszy spotkali się właśnie na tym Kongresie. Rutherford w liście do matki tak opisywał swoje wrażenia z tego spotkania: „Wygląda bardzo mizernie, na zmęczoną i dużo starszą niż jest w rzeczywistości. Pracuje zbyt ciężko jak na jej zdrowie. Wziąwszy to wszystko razem - bardzo wzruszająca postać"14.

Rutherford kongresowe kontakty ze Skłodowską-Curie dość dokładnie opisywał w korespondencji ze wspomnianym Boltwoodem - swoim przyjacielem i współpracownikiem, uczestnikiem spotkania w Brukseli. Po zakończeniu Kongresu (który Boltwood musiał wcześniej opuścić) Rutherford donosił, że Skłodowska-Curie nie czuła się dobrze pod koniec obrad - była porządnie przeziębiona i Rutherford, który w trakcie przedstawienia w operze siedział obok, musiał w połowie spektaklu wyprowadzić ją stamtąd. Na drugi dzień czuła się tak marnie, że nie wzięła udziału w uroczystym obiedzie, ale wystarczająco dobrze, żeby następnego ranka odjechać wraz z Jeanem Perrinem ${ }^{15}$ do Paryża. Zdaniem Rutherforda, Skłodowska-Curie przepracowywała się, a ponadto jej nerwy były w bardzo złym stanie ${ }^{16}$.

Przed opuszczeniem Brukseli Skłodowska-Curie przesłała Rutherfordowi krótki list, w którym przepraszała, że z powodu choroby nie zobaczyła się z nim przed wyjazdem. Dziękowała za to, że mówił o niej poprzedniego wieczora w sposób tak ciepły i przyjazny. Pisała: „Byłam mile poruszona względami, jakie mi Pan okazał podczas tego Kongresu i chciałam uścisnąć Pana dłoń przed wyjazdem. Nie mając tej przyjemności, żegnam Pana tym listem z najlepszymi uczuciami"17.

Rutherford dość pobłażliwie odnosił się do wystąpień francuskich kolegów na Kongresie. Pisał do Boltwooda:

12 CUL, Add 7653, C 97, list z 6.09.1910. Drugim wprowadzonym przez Skłodowską-Curie członkiem Komisji miał być Egon Schweidler, reprezentujący Austrię.

13 J. Hurwic, Maria Skłodowska-Curie i promieniotwórczość, Warszawa 2001, s. 73.

14 Cyt. za J. Rowland, Ernest Rutherford Atom Pioneer, New York 1957, s. 69.

15 Jean Perrin (1870-1942) - fizyk i chemik francuski. Profesor (od 1910 r.) Sorbony, prezes francuskiej Akademii Nauk, laureat Nagrody Nobla w 1926 r. Główny organizator badań naukowych we Francji. Twórca Palais de la Découverte w Paryżu oraz Centre National de la Recherche Scientifique (w 1939 r.).

16 Rutherford and Boltwood. Letters on Radioactivity, s. 225, list z 27.09.1911.

17 CUL, Add 7653, C 100, list z [15].09.1910. 
Całą środę przewodniczyłem spotkaniom. Perrin dał dobry referat o swoich eksperymentach dotyczących ruchów Browna i był bardzo żwawy i podskakujący jak jack-in-the-box [diabełek z pudełka]. Zażartowałem jedyny raz na spotkaniu, mówiąc, że Profesor Perrin sam jest godnym podziwu przykładem ruchów Browna. Perrin, Becquerel i paru innych Francuzów zabrało nam całą godzinę, mówiąc o starych pracach sprzed około trzech lat. Oni są niepoprawni jeśli chodzi o rozwlekłość wypowiedzi ${ }^{18}$.

Na tym samym Kongresie, na wniosek Skłodowskiej-Curie, ustalono jednostkę promieniotwórczości. Przyjęto jednostkę, którą na cześć Piotra Curie nazwano curie (Ci). Miała to być aktywność takiej ilości emanacji, która pozostaje w równowadze z 1 gramem radu, tj. takiej ilości emanacji powstającej z radu, w której liczba rozpadających się atomów równa się liczbie atomów rozpadających się w 1 gramie radu w ciągu tego samego czasu ${ }^{19}$.

W tym okresie nastąpiło wyraźne wzmocnienie kontaktów między Skłodowską-Curie i Rutherfordem, co się uzewnętrzniło m.in. poprzez rozpoczęcie wysyłania własnych uczniów do konkurencyjnego laboratorium na staże badawcze. W maju 1911 r. Skłodowska-Curie rekomendowała May Leslie, która w Laboratorium Curie zajmowała się analizą minerałów zawierających radioaktywny tor. Udała się do laboratorium Rutherforda na roczny pobyt badawczy ${ }^{20}$. W późniejszym okresie jeszcze kilku innych uczniów Skłodowskiej-Curie znajdzie się w laboratorium Rutherforda, m.in. Ludwik Wertenstein. Także Rutherford wyśle paru swoich uczniów do Laboratorium Curie ${ }^{21}$.

Skłodowska-Curie przygotowała wzorzec radowy już w sierpniu 1911 r., ale do jego formalnego przyjęcia miało jeszcze upłynąć sporo czasu. Podstawową przeszkodą było stanowisko samej Skłodowskiej-Curie, która nie zamierzała wzorca nikomu przekazywać. Zapowiadała to zresztą w swoim, cytowanym powyżej, liście do Rutherforda jeszcze przed Kongresem Radiologicznym. Rutherford o przebiegu pertraktacji w tej sprawie dokładnie informował Boltwooda - uczestnika Kongresu w Brukseli. W liście z 20 listopada 1911 r. napisał mu, że spotkał Skłodowską-Curie na Konferencji Solvaya w Brukseli i rozmawiał z nią (o północy, czego nie omieszkał zaznaczyć) na temat wzorca. Skłodowska-Curie oświadczyła, że chciałaby zachować wzorzec w swoim laboratorium - częściowo ze względów "sentymentalnych", a częściowo dlatego, aby kontynuować obserwacje jego aktywności. Rutherford oponował, podkreślając, że Komisja nie może się zgodzić, żeby międzynarodowy wzorzec pozostawał w prywatnych rękach. „Jak Pan wie - pisał Rutherford do Boltwooda - ona jest bardzo uparta, ale po dyskusji zasugerowała, że mogłaby złożyć w jednej z francuskich instytucji duplikat, który zostanie uznany za wzorzec"22. $\mathrm{Na}$ to Komisja nie chciała się zgodzić. Skłodowska-Curie dała także do zrozumienia, że

18 Rutherford and Boltwood. Letters on Radioactivity, s. 225, list z 27.09.1910.

19 J. Hurwic, op. cit., s. 74.

20 CUL, Add 7653, C 99, list M. Curie do E. Rutherforda z 24.05.1911. W liście do Boltwooda z 18.03.1912 Rutherford, omawiając badania prowadzone przez jego współpracowników w laboratorium napisał że „miss Leslie is comparing accurately the diffusion constants of the thorium and actinium emanations". Swoją pracę na ten temat opublikowała w tymże 1912 r. w „Philosophical Magazine”. Rutherford and Boltwood. Letters on Radioactivity, s. 265 i $267-268$.

21 Brakuje bliższych danych na ich temat.

22 Rutherford and Boltwood. Letters on Radioactivity, s. 258, list z 20.11.1911. 
koszt przygotowania i przetestowania każdego wzorca, oprócz kosztu radu, wynosi tysiąc franków i „zleciła” Rutherfordowi, aby zapytał austriackiego członka Komisji, Stefana Meyera ${ }^{23}$, czy rząd austriacki mógłby dostarczyć rad za rozsądną cenę (jako ekwiwalent za rad użyty do wykonania wzorca). Dalej Rutherford zawiadamiał Boltwooda, że Meyer opracuje wzorzec radowy, który zostanie porównany z wzorcem Skłodowskiej-Curie. Był przekonany, że świadomość istnienia drugiego wzorca skłoni ją do większego umiarkowania. Przy okazji odniósł się do świeżych rewelacji prasy francuskiej na temat romansu Skłodowskiej-Curie z „jego starym przyjacielem" fizykiem Paulem Langevinem ${ }^{24}$. Rutherford był przekonany, że są one „wzięte z księżyca”, ale przyznawał jednocześnie, że dla obojga jest to raczej „nieszczęsna sprawa”25.

Powołana na Kongresie Radiologii i Elektryczności międzynarodowa Komisja do sprawy wzorca radowego nie zamierzała zgodzić się na pozostawienie go w laboratorium Skłodowskiej-Curie. Komisja uważała, że powinien się on znaleźć w Międzynarodowym Urzędzie Miar i Wag (Bureau International des Poids et Mesures) w Sevres pod Paryżem. Rutherford był swego rodzaju pośrednikiem i mediatorem pomiędzy komisją i Skłodowską-Curie, doskonale wypełniając te obie funkcje. W liście do Boltwooda wspominał, że zaprosił Skłodowską-Curie do Manchesteru na otwarcie swojego rozbudowanego laboratorium, a przy tej okazji zostanie jej przyznany honorowy stopień (doctora honoris causa Uniwersytetu w Manchesterze). „Myślę - pisał Rutherford - że tego rodzaju drobiazgi pomogą w załagodzeniu konfliktu". Wspomniał, że jest bardzo zadowolony z przyznania w tymże 1911 r. Skłodowskiej-Curie Nagrody Nobla, chociaż myślał, że to chemik amerykański Richards będzie laureatem ${ }^{26}$.

Z ciepłym zaproszeniem do Manchesteru wystąpił nie tylko Rutherford, lecz także jego żona Mary. Zapraszała Skłodowską-Curie do spędzenia paru dni w domu Rutherfordów, chciała jej także pokazać okolice Manchesteru27.

Mimo postępującej choroby Skłodowska-Curie zdecydowała się na wyjazd. Dziękując małżeństwu Rutherfordów za zaproszenie, informowała, że przyjedzie do Manchesteru na 23 lutego (1912 r.) - kiedy miała mieć miejsce cała uroczystość. Pisała: „Miałam tyle kłopotów w ostatnim czasie i byłam tak cierpiąca, że nawet przy najlepszej chęci mogło to przeszkodzić w wyjeździe. Ale może Pan liczyć na to, że przyjadę, chyba że będę zbyt chora". Pytała, czy może zabrać ze sobą córkę Irenę ${ }^{28}$, ponieważ nie lubi podróżować sama. Informowała także Rutherforda o swoich ostatnich pracach ${ }^{29}$.

23 Stefan Meyer (1872-1949) - fizyk austriacki, pracujący na uniwersytecie w Wiedniu, dyrektor bardzo znanego Instytutu Radowego w Wiedniu. Zajmował się fizycznymi stronami promieniowania, m.in. odkrył, że promienie uranu są jednak odchylane w polu magnetycznym.

24 Paul Langevin (1872-1946) - fizyk francuski. Od 1903 r. był profesorem, a następnie dyrektorem École de Physique et de Chimie Industrielle de la Ville de Paris. Od 1909 r. profesor Collège de France. Przewodniczący Komitetu Naukowego Konferencji Solvaya w latach 1928-1939. Prowadził badania m.in. nad jonizacją gazów, magnetyzmem i ultradźwiękami. Zajmował się także fizyką teoretyczną.

25 Rutherford and Boltwood. Letters on Radioactivity, s. 257.

26 Ibid., s. 258-259. Theodore W. Richards - profesor chemii na Harvard Uniwersity, laureat Nagrody Nobla w $1914 \mathrm{r}$.

27 BN, k. 362-364, list z 18.12.1911.

28 Irena Curie (1897-1956) - żona Frédérica Joliota. Fizyk i chemik, profesor Sorbony od 1937 r., od 1946 r. dyrektor Instytutu Radowego w Paryżu, prowadziła badania z zakresu promieniotwórczości i reakcji jądrowych. W 1934 r. odkryła wraz z mężem zjawisko sztucznej promieniotwórczości, za co w 1935 r. obydwoje otrzymali Nagrodę Nobla.

29 CUL, Add 7653, C 101-102, listy M. Curie do M. i E. Rutherfordów z 28.12.1911. 
Rutherford odpisał na początku stycznia. Wyrażał radość z zapowiedzianych odwiedzin. Oczywiście zapraszał także (czternastoletnią) Irenę. Pisał, że jego (dziesięcioletnia) córka chętnie dotrzyma jej towarzystwa. Miał nadzieję, że Irena choć trochę mówi po angielsku. Zawiadamiał, że data uroczystości uległa niewielkiemu przesunięciu i sugerował drobne zmiany w przebiegu podróży do Manchesteru ${ }^{30}$.

$\mathrm{Na}$ ten list Skłodowska-Curie jednak już nie odpowiedziała. Zachorowała obłożnie. Na marginesie otrzymanego od Rutherforda listu napisała po polsku: „Debierne odpowiedział"'31. Doktorat honoris causa w Manchesterze odebrała w późniejszym czasie.

Ustalono, że porównanie wzorców radowych przygotowanych przez Skłodowską-Curie i Stefana Mayera odbędzie się w Paryżu, w obecności komisji. Chorą Skłodowską-Curie miał reprezentować Debierne. „Nie mam wątpliwości - pisał Rutherford w liście do Boltwooda - że oba wzorce będą ze sobą zgodne, ale będzie diabelna awantura, jeśli stanie się inaczej. To jest jedna z przyczyn, dla której muszę tam być, aby wystąpić w roli arbitra wobec dwóch stron"32.

W kolejnym liście do Boltwooda Rutherford opisał przebieg paryskiego spotkania. Oba wzorce okazały się identyczne. Spotkanie komisji przebiegło w bardzo miłej atmosferze i bez żadnych zadrażnień. Debierne doskonale przygotował aparat do testowania wzorców i okazał się bardzo kontaktową osobą. Wszyscy zjedli lunch w mieszkaniu Skłodowskiej-Curie z nią i z jej córkami. Zdaniem Rutherforda, Skłodowska-Curie wyglądała na słabą i chorą, „ale nie gorzej niż w Brukseli dwa lata wcześniej”. Po krótkim spotkaniu w jej mieszkaniu powrócono do Laboratorium dla dokonania ostatecznych ustaleń, z których SkłodowskaCurie była całkowicie zadowolona. Według Rutherforda, bez niej prace nad wzorcem przebiegłyby dużo szybciej, bowiem miała ona skłonność do stwarzania trudności. Rutherford podniósł też w czasie spotkania komisji kwestię pokrycia kosztów przygotowania wzorca. Zgodzono się, że rzeczą komisji jest zdobycie tych środków i każdy z jej członków zobowiązał się do indywidualnych starań o ich pozyskanie. Główną rolę w tym zakresie odegrał, jak się wydaje, Frederick Soddy ${ }^{33}$, którego krewni - zamożni przemysłowcy brytyjscy - zgodzili się sfinansować całe przedsięwzięcie. Rutherford wyrażał zadowolenie, że to strona brytyjska, a nie francuska sfinansuje przedsięwzięcie oraz że będą to środki prywatne, a nie państwowe. Uniemożliwi to bowiem ingerencję państwa w prace komisji34.

Niecały rok później - w lutym 1913 r. - Skłodowska-Curie wraz z André Debiernem złożyła w Międzynarodowym Urzędzie Miar i Wag w Sevres probówkę zawierającą 21,99 miligramów czystego chlorku radu - jako wzorzec, z którym odtąd miano porównywać standardy radowe na całym świecie ${ }^{35}$.

Nie był to jednak koniec całej procedury związanej ze wzorcem. Być może zaistniały jakieś przeszkody formalne lub materialne, bowiem wzorzec został prawdopodobnie na jakiś czas wycofany z Urzędu Miar i Wag. Tak przynajmniej można wnosić z listu Skłodow-

Ibid., k.336.

32 Rutherford and Boltwood. Letters on Radioactivity, s. 264, list z 18.03.1912.

33 Frederic Soddy (1877-1956) - brytyjski chemik i fizyk, profesor uniwersytetów w Aberdeen i w Oksfordzie, członek Royal Society, jeden z twórców nauki o promieniotwórczości, współpracownik Rutherforda. Za badania nad izotopami otrzymał w 1922 r. Nagrodę Nobla.

34 Ibid., s. 270. List z 22.04.1912.

35 J. Hurwic, op. cit., s. 73-74. 
skiej-Curie do Rutherforda z 30 maja 1913 r., w którym zapowiada jednak, że wzorzec ponownie zostanie tam wysłany. W tym samym liście informuje Rutherforda, że po chorobie wróciła już do pracy, ale w dalszym ciągu nie czuje się dobrze ${ }^{36}$.

W liście do Boltwooda z 21 października 1911 r. Rutherford pisał: „Pomijając moje przeziębienie, jestem w doskonałej formie. W końcu następnego tygodnia zamierzam pojechać do Brukseli, żeby wziąć udział w małej konferencji, około piętnaście osób, na temat teorii promieniowań. Paru bogatych ludzi w Brukseli płaci po tysiąc franków każdy na nasze wydatki. To jest taki rodzaj konferencji, w których mogę uczestniczyć bez żadnych oporów. Planck, Lorentz, Nernst, Jeans i inni będą obecni, a ja mam nadzieję także spotkać Madame Curie"37.

Konferencja, o której pisał Rutherford, to pierwsza z całej serii słynnych Konferencji Solvaya, w których udział brali najwybitniejsi ówcześnie fizycy i chemicy, zorganizowanych przez chemika i przemysłowca belgijskiego Ernesta Solvaya ${ }^{38}, \mathrm{z}$ inspiracji Waltera Nernsta ${ }^{39}$, niemieckiego naukowca zajmującego się chemią fizyczną oraz z pomocą wybitnego fizyka holenderskiego Hendrika A. Lorentza ${ }^{40}$. Miały one stanowić forum wymiany myśli na temat nowych teorii w fizyce. Na tę pierwszą konferencję zaproszonych zostało 22 najważniejszych ówcześnie fizyków europejskich. Oprócz Skłodowskiej-Curie udział w niej wzięli m.in. Max Planck, Ernest Rutherford, Henri Poincare, Albert Einstein oraz Lorentz, który jej przewodniczył. Wygłoszono 11 referatów, po których dochodziło do ożywionych, a nawet burzliwych dyskusji. Konferencja solvayowska przyczyniła się do uformowania międzynarodowej grupy najwybitniejszych fizyków, którzy mieli w późniejszym czasie decydować o rozwoju tej dziedziny nauki. Pierwsza Konferencja Solvaya w Brukseli była początkiem całej serii zjazdów najwybitniejszych uczonych, debatujących nad najważniejszymi zagadnieniami fizyki i chemii. W tej konferencji, w dniach od 30 października do 3 listopada 1911 r. w brukselskim hotelu Metropol, udział wzięło 9 aktualnych lub przyszłych laureatów Nagrody Nobla. Następne miały się odbywać co dwa lata. Pierwsza Konferencja poświęcona była bardzo wtedy aktualnym tematom: teorii promieniowania i kwantom. Zaproszeni zostali przez Solvaya, z inspiracji W. Nernsta i H. A. Lorentza, ci uczeni, którzy tymi zagadnieniami w sposób bezpośredni lub pośredni się zajmowali. Lorentz będzie jeszcze przewodniczył kolejnym czterem konferencjom (odbywały się co dwa lata, z przerwą w okresie I wojny światowej), a po jego śmierci (w 1928 r.) przewodnictwo obejmie Paul Langevin. Sprawozdanie z I Konferencji Solvayowskiej opublikowane zostało przez jej dwóch francuskich uczestników: właśnie Langevina i Maurice'a de Broglie'a ${ }^{41}$.

37 Rutherford and Boltwood. Letters on Radioactivity, s. 255.

38 Ernest Solvay (1838-1922) - belgijski chemik, przemysłowiec i filantrop. Wraz z bratem opracował metodę otrzymywania sody (tzw. metoda Solvaya). Wspólnie założyli firmę Solvay, której działalność od lat siedemdziesiątych XIX w. stopniowo objęła cały świat.

39 Walter Nernst (1864-1941) - niemiecki chemik i fizyk, w latach 1891-1905 profesor uniwersytetu w Getyndze, a od 1905 w Berlinie. W latach 1924-33 dyrektor Instytutu Fizyki w Berlinie. Prowadził badania w zakresie termodynamiki, fizyki niskich temperatur i chemii fizycznej. W 1920 r. za prace z zakresu termodynamiki otrzymał Nagrodę Nobla.

40 Hendrik Antoon Lorentz (1853-1928) - fizyk holenderski, od 1878 r. profesor fizyki teoretycznej na Uniwersytecie w Lejdzie. W 1912 r. zrezygnował z katedry, obejmując stanowisko dyrektora Instytutu Teylera w Haarlem. Jednak do końca życia prowadził wykłady na uniwersytecie. Uznawany za jednego z najwybitniejszych fizyków swego czasu. W 1902 r. otrzymał Nagrodę Nobla z fizyki.

41 La théorie du rayonnement et les quanta. Rapports et discussions, Paris 1912. O dziejach Konferencji Solvaya najwięcej dowiedzieć się można ze źródłowej książki: Jagdish Mehra, The Solvay Conferences on Physics: 
Skłodowska-Curie nie tylko wzięła udział we wszystkich Konferencjach solvayowskich aż do 1933 r. (było ich siedem), ale stała się jedną z najważniejszych osób, które wpłynęły na ich taką, a nie inną organizację. Współpracowała w tym zakresie przede wszystkim z Lorentzem, a następnie także z Langevinem, Einsteinem i Rutherfordem.

Główną „sprężyną" był Lorentz, który w porozumieniu z Solvayem i jego pełnomocnikiem miał nadać formę organizacyjną tym cyklicznym spotkaniom. W dzieło to, mimo złego stanu zdrowia, aktywnie włączyła się także Skłodowska-Curie, o czym możemy wnosić m.in. z opublikowanych przez Karin Blanc listów Lorentza i Skłodowskiej-Curie ${ }^{42}$.

W związku z planowaną na 1913 r. Konferencją Solvayowską (Conseil de Physique) Lorentz postanowił zwołać międzynarodową radę naukową do Brukseli w dniach 30 września - 1 października. Pytał Skłodowską-Curie o opinię w sprawie dołączenia do ośmiu już wybranych członków rady, jako dziewiątego, Roberta Goldschmidta ${ }^{43}$. Nie miała nic przeciw tej propozycji, podkreślając wsparcie Goldschmidta dla inicjatywy Solvaya ${ }^{44}$. Ostatecznie więc ta pierwsza międzynarodowa rada naukowa, która przyjęła nazwę komitetu naukowego Międzynarodowego Instytutu Fizyki Solvaya (Comité scientifique de I'Institut International de Physique Solvay) miała liczyć dziewięciu członków. W jej skład weszli: Hendrik Lorentz - jako przewodniczący oraz Maria Skłodowska-Curie, Marcel Brillouin, Robert Goldschmidt, Heike Kamerlingh Onnes, Martin Knudsen, Walther Nernst, Ernest Rutherford, Emil Wartburg. Knudsen został sekretarzem komitetu.

Skłodowska-Curie chciała przyjechać na to pierwsze posiedzenie komitetu naukowego. Niestety, na przeszkodzie stanął jej stan zdrowia. Pisała do Lorentza z Anglii, gdzie przebywała u swej przyjaciółki Herthy Ayrton:

Byłam bardzo ciężko chora wiele miesięcy i dopiero zaczynam czuć się trochę lepiej. Muszę unikać wszelkich powodów do zmęczenia. Byłabym prawdopodobnie w stanie odbyć tą podróż - pomimo że są dni kiedy bardzo cierpię [...] Dlatego byłabym Panu bardzo wdzięczna za wyrażenie swojej opinii, czy jest konieczne, żebym zrobiła ten wysiłek w związku ze sprawami, które mają być dyskutowane. Jest mi bardzo przykro, że mogę dać w ten sposób Panu Solvayowi wrażenie, że nie wykazuję wystarczającego zainteresowania dla jego wspaniałej inicjatywy i odmawiam współdziałania w jego dziele. Jednak ze względu na moje zdrowie myślę, że byłoby lepiej, gdybym była nieobecna, zwłaszcza gdyby moja obecność nie była rzeczywiście bardzo potrzebna ${ }^{45}$.

W swojej odpowiedzi Lorentz wyraził żal z powodu ciągle złego stanu zdrowia Skłodowskiej-Curie i konieczności oszczędzania przez nią sił. W tej sytuacji wyraził przekonanie, że jej przyjazd, aczkolwiek bardzo pożądany, nie jest konieczny. Proponował, żeby wcześniej przysłała mu swoje uwagi dotyczące poruszanych na posiedzeniu komitetu naukowego kwestii, o których zamierzał ją informować ${ }^{46}$.

Aspects of the Development of Physics since 1911, Boston 1975. Zob. także J. Piskurewicz, Zakochana w fizyce. Udział i rola Marii Skłodowskiej-Curie w organizacji i pracach konferencji Solvaya, "Analecta” 2017, nr 1.

42 K. Blanc, op. cit., s. 206-220.

43 Robert Goldschmidt (1877-1935) - belgijski chemik i fizyk, wynalazca oraz bankier. W nauce odegrał istotną rolę $w$ badaniach $w$ zakresie termodynamiki chemicznej.

44 Ibid., s. 216, list z 15.09.1912.

45 Ibid.

46 Ibid., s. 217, list z 20.09.1912. 
Skłodowska-Curie odpowiedziała w dwa dni potem ( $w$ tamtym czasie listy dochodziły znacznie szybciej niż obecnie). Pisała, że przyjedzie do Brukseli jedynie wtedy, gdy będzie czuła się dobrze. Zakładała taką możliwość, bowiem uważała, że same spotkania komitetu naukowego nie będą bardzo męczące. Pozostawała jednak podróż, która przy jej stanie zdrowia mogła źle wpłynąć na proces rekonwalescencji. Zapytywała, czy będzie obecny Rutherford ${ }^{47}$.

Ostatecznie Skłodowska-Curie nie przybyła na posiedzenia komitetu naukowego do Brukseli. Otrzymała jednak dość dokładne informacje właśnie od Rutherforda, który wziął w nich udziat.

Rutherford donosił, że komitet ustalił wstępny plan działania dotyczący regulacji prawnych oraz rozważył kwestię grantów, a także miejsca i czasu przyszłej konferencji. Uznano, że spotkanie to powinno mieć miejsce w październiku następnego roku, a tematem jakieś zasadnicze zagadnienie dotyczące struktury materii. Wszyscy zaproszeni na pierwszą Konferencję Solvaya będą znowu zaproszeni, a oprócz nich jeszcze kilka osób. Między innymi Joseph John Thomson ${ }^{48}$, który miał zostać poproszony o referat na temat struktury materii oraz Max von Laue, którego chciano poprosić o referat na temat „promieni X w związku z kryształami"49. Postanowiono utworzyć grant dla uczonych rosyjskich i jeszcze dwa dodatkowe - jeden dla Laue'a na prace z promieniami X i jeden dla Charlesa Barkli50 na prace nad charakterystyką promieni X. Sprawa następnych grantów miała zostać rozważona w terminie późniejszym, kiedy zagadnienia zostaną ogłoszone w tych czasopismach naukowych, do których wysłano informację o genezie i intencjach Międzynarodowego Instytutu Solvaya. W czasie obrad panowała bardzo przyjemna atmosfera, Lorentz prowadził je w doskonały sposób. Zdaniem Rutherforda, Instytut Solvaya będzie dobrym i ważnym czynnikiem pracy badawczej. Pytał, czy może być w czymś pomocny Skłodowskiej-Curie i zapewniał, że z przyjemnością zrobi dla niej wszystko, co tylko będzie mógł51.

W swojej odpowiedzi Skłodowska-Curie odniosła się przede wszystkim do wyboru grantobiorców. Uznała, że wszystkie subwencje są dobrze przyznane i że Fundacja (Instytut) Solvaya $w$ ten sposób odegra istotną rolę we wspieraniu badań naukowych ${ }^{52}$. Warto dodać, że po utworzeniu Pracowni Radiologicznej przy Towarzystwie Naukowym Warszawskim, którego była honorowym kierownikiem, Skłodowska-Curie zwróciła się do Instytutu Solvaya, a właściwie do międzynarodowego komitetu naukowego Instytutu o przyznanie Pracowni subwencjij ${ }^{53}$ W tym celu napisała wcześniej do Rutherforda, aby zyskać jego

47 Ibid., s. 219, list z 22.09.1912.

48 Joseph John Thomson (1856-1940) - fizyk brytyjski, profesor Uniwersytetu w Cambridge, w latach 1884-1919 kierował Cavendish Laboratory (po nim objął to stanowisko Rutherford). Odkrył elektron, za doświadczalne i teoretyczne badania nad przepływem prądu elektrycznego przez gazy i odkrycie swobodnych elektronów otrzymał w 1906 r. Nagrodę Nobla.

49 Chodziło o odkrycie dyfrakcji promieni X na kryształach, za co Laue w 1914 r. otrzymał Nagrodę Nobla. Max von Laue (1879-1960) - fizyk niemiecki, profesor uniwersytetów m.in. w Zurichu i Berlinie, prekursor analizy rentgenowskiej.

50 Charles Barkla (1877-1944) - fizyk brytyjski, pracował na uniwersytetach w Cambridge i Liverpoolu, odkrył dwie serie rentgenowskiego promieniowania charakterystycznego, co było istotnym etapem w rozwoju teorii atomu. Za to odkrycie otrzymał w 1917 r. Nagrodę Nobla z fizyki.

51 BN, k. 338-340, list z 4.10.1912.

52 CUL, Add 7653, C 103, list z 17.10.1912.

53 K. Blanc, op. cit., s. 227-229, list z czerwca 1914. 
poparcie $^{54}$. Wystąpiła o przyznanie 3800 do 4000 franków, na co komitet wyraził zgodę, przyznając Pracowni 4000 franków na badania promieni $\beta$ wysyłanych przez rad ${ }^{55}$.

Drugą kwestią, którą poruszyła był proponowany temat kolejnej Konferencji solvayowskiej. Uważała, że temat jest bardzo interesujący i aktualny, ale z drugiej strony, zdaniem Skłodowskiej-Curie, zbyt mało wiedziano w tym czasie na temat struktury materii, ażeby robić na ten temat konferencję. Nie spodziewała się, żeby w najbliższym czasie nastąpił postęp $\mathrm{w}$ tym zakresie. $\mathrm{W}$ tym kontekście uznała ewentualne referaty Thomsona $\mathrm{i}$ von Lauego za wielce obiecujące ${ }^{56}$.

Druga Konferencja solvayowska miała miejsce w Brukseli w dniach 27-31 października 1913 r. W centrum zainteresowania uczestników było wspomniane już odkrycie dyfrakcji promieni Röntgena w kryształach, dokonane przez von Laue'go w 1912 r. Otwierało ono nowe drogi w poznawaniu struktury materii ${ }^{57}$.

Na Konferencji dyskutowano także o strukturze materii w oparciu o model atomu Thomsona, co do którego modelu Skłodowska-Curie miała poważne zastrzeżenia ze względu na to, że nie zgadzał się on z prawami transformacji pierwiastków radioaktywnych. W dyskusji po referacie Thomsona w dłuższym wystąpieniu wyjaśniała swoje stanowisko, powołując się m.in. na pracę swego współpracownika i przyjaciela - Debierne'a. Poparł ją Ernest Rutherford. Krytycznie do modelu Thomsona odniósł się także Lorentz ${ }^{58}$.

W 1915 r. miał się odbyć kolejny Kongres Radiologii. Głównym inicjatorem był Rutherford, który już w 1913 r. zwrócił się do Skłodowskiej-Curie z zapytaniem co do sugerowanego czasu i miejsca. Proponował odbyć spotkanie w czerwcu w Wiedniu. O ile Skłodowska-Curie nie miała zastrzeżeń co do miejsca, o tyle wskazywała, że czerwiec nie jest dobrym miesiącem, ponieważ trwają jeszcze zajęcia uniwersyteckie ${ }^{59}$. W każdym razie to Wiedeń miał gościć uczestników Kongresu i to austriaccy uczeni mieli być gospodarzami tego wydarzenia. Oni też, siłą rzeczy, dominowali w proponowanym składzie komitetu organizującego Kongres. Generalnym sekretarzem zostać miał profesor Stefan Meyer ten sam, który wykonał wzorzec radowy porównywany z wzorcem przygotowanym przez Skłodowską-Curie. Na przewodniczącego Kongresu Skłodowska-Curie proponowała Rutherforda. Oprócz nich obojga i Meyera, w skład sześcioosobowego komitetu organizacyjnego weszło trzech profesorów austriackich - także fizyków i fizykochemików. Biorąc pod uwagę znaczenie badań nad promieniotwórczością dla medycyny, Skłodowska-Curie proponowała stworzenie w ramach komitetu organizacyjnego jeszcze podkomitetu me-

54 CUL, Add 7653, C 109, list z 13.01.1914.

55 K. Blanc, op. cit., s. 229.

56 CUL, Add 7653, C 103, list z 17.10.1912.

57 Referat von Laue'go i dyskusja nad nim w: La structure de la matière. Rapports et discussions du Conseil de Physique tenu a Bruxelles du 27 au 31 octobre 1913 sous les auspices de I'Institut International de Physique Solvay, Paris 1921, s. 75-112.

58 Wystąpienie Skłodowskiej-Curie zostało potraktowane w wydanych materiałach z konferencji jako osobny referat. Było zatytułowane Sur la loi fondamentale des transformations radioactives. Zob. La structure de la matière, s. 45-46, 55-56 oraz 66-71. Zob. także O. Starosielska-Nikitina, H. Starosielska, Rola Marii Skłodowskiej-Curie w rozwoju fizyki jądrowej, [w:] Studia poświęcone Marii Skłodowskiej-Curie i Marianowi Smoluchowskiemu, Wrocław 1968, s. 76.

59 CUL, Add. 7653, C 107, M. Curie do E. Rutherforda z 22.11.1913. W zakończeniu listu pisała: „Mam dużo pracy ostatnio z budową mojego nowego laboratorium, a dzisiaj wyjeżdżam do Warszawy na otwarcie Laboratorium Radiologicznego" (chodziło o otwarcie Pracowni Radiologicznej przy Towarzystwie Naukowym Warszawskim). 
dycznego. W liście do Rutherforda wymieniała nazwiska tych lekarzy, którzy zajmowali się radiologią we Francji ${ }^{60}$.

Wiedeński Kongres Radiologiczny w 1915 r. nie doszedł do skutku, bowiem już w sierpniu 1914 r. wybucha wojna.

Skłodowska-Curie w swojej Autobiografii dokładnie podaje czym zajmowała się w okresie wojny. Przede wszystkim zdecydowała się zabezpieczyć rad znajdujący się w jej laboratorium, aby nie wpadł w ręce Niemców, którzy znajdowali się już niebezpiecznie blisko Paryża. Wywiozła go osobiście, z dużym poświęceniem, do Bordeaux. Wiedzę swą Skłodowska-Curie postanowiła wykorzystać w organizacji służby radiologicznej i radioterapeutycznej w szpitalach wojskowych. Już od sierpnia 1914 r. zaczęła tworzyć stacje radiologiczne (powstało ich około dwustu), a we własnym laboratorium zaadaptowała i przekazała wojsku dwadzieścia samochodów radiologicznych. Samochody te zostały darowane przez osoby prywatne. Wszystkie te ośrodki radiologiczne miały szczególne znaczenie w pierwszych dwóch latach wojny, bowiem armia francuska miała bardzo mało urządzeń tego typu. Z czasem sytuacja się poprawiła, ale i tak współpraca SkłodowskiejCurie w tym zakresie okazała się konieczna aż do końca wojny, a nawet dłużej61.

Od 1915 r. Skłodowska-Curie rozpoczęła także przenosiny swojego laboratorium do nowego gmachu Instytutu Radowego. W warunkach wojennych i przy jej licznych zajęciach było to zadanie trudne i męczące, zwłaszcza że brakowało czasu, pieniędzy i odpowiednich ludzi. „Tak więc - wspominała Skłodowska-Curie - tylko między jedną a drugą podróżą mogłam powoli przewozić urządzenia laboratoryjne swoim wozem radiologicznym". W urządzaniu Instytutu pomagała jej tylko córka Irena i mechanik, „który na nieszczęście często chorował"62.

We Francji dopiero w październiku 1915 r., kiedy ministrem edukacji został znany uczony Paul Painlevé63, zaczęto organizować „mobilizację naukową” na rzecz wojny. Wtedy to właśnie władze wojskowe zaprosiły Langevina do udziału w pracach z zakresu balistyki, a w jakiś czas później jego były uczeń Maurice de Broglie ${ }^{64}$ - w tamtym czasie oficer marynarki wojennej i wykładowca w wyższej szkole marynarki - zaproponował mu zajęcie się zagadnieniem namierzania nieprzyjacielskich łodzi podwodnych. W marcu 1917 r. Langevin udał się do Londynu, aby przedyskutować w Admiralicji ewentualną współpracę z Anglikami w tym zakresie. Przedstawił tam rezultaty swoich prac i wkrótce Wielka Brytania zdecydowała się przeprowadzić analogiczne badania pod opieką Langevina w Harwich. Ze strony brytyjskiej już wcześniej zajął się nimi także Ernest Rutherford. We wrześniu 1915 r. pisał do Boltwooda, że został mianowany członkiem Rady do Spraw Wynalazków i Badań (Board of Inventions and Research), a jego szczególnym zainteresowaniem cieszą się kwestie dotyczące łodzi podwodnych i już podjął badania nad ich wykrywaniem przy

60 Ibid., C 108, list z 14.12.1913.

61 M. Skłodowska-Curie, Autobiografia, Warszawa 2004, s. 41.

62 Ibid., s. 46

63 Paul Painlevé (1863-1933) - francuski matematyk i polityk, od 1891 r. profesor Sorbony, od 1915 r. wielokrotny minister różnych resortów, w 1917 r. i 1925 r. premier.

64 Maurice de Broglie (1875-1960) - francuski oficer marynarki wojennej i fizyk. W 1893 r. ukończył Szkołę Morską ze stopniem majora. Wykładowca w szkolnictwie morskim. Zajął się także fizyką i w 1908 r. obronił pracę doktorską na temat gazów jonizujących. Był uczniem i współpracownikiem Langevina, a w 1911 r. sekretarzem Konferencji Solvaya. Wspólnie z Langevinem opublikował wtedy referaty z tej Konferencji. 
pomocy akustyki ${ }^{65}$. Oprócz Rutherforda tymi zagadnieniami zajmowali się także inni brytyjscy fizycy, m.in. W.H. Bragg i A.S. Eve ${ }^{66}$.

Rutherford podszedł do nowych zadań z charakterystycznym dla niego entuzjazmem. W swoim laboratorium w Manchesterze zainstalował olbrzymi pojemnik z wodą, który służył mu do doświadczeń. Oprócz łodzi podwodnych, zajął się także podwodnymi minami i związanymi z nimi urządzeniami ${ }^{67}$.

Zainteresowano się tymi zagadnieniami także w USA. Po przystąpieniu Stanów Zjednoczonych do wojny w 1917 r. Rutherford udał się tam na czele delegacji brytyjskiej, żeby przedstawić nowe rozwiązania naukowo-techniczne mogące być wykorzystane w działaniach wojennych. Realizowany projekt nabrał więc międzynarodowego charakteru. W październiku 1918 r. zwołano do Paryża specjalną konferencję aliantów poświęconą wykrywaniu łodzi podwodnych za pomocą fal ultradźwiękowych. Szereg rozwiązań i konstrukcji urządzeń opracowanych wtedy było chronionych francuskimi, brytyjskimi i międzynarodowymi patentami ${ }^{68}$.

Po wojnie jedną ze spraw żywiej dyskutowanych przez Skłodowską-Curie i Ernesta Rutherforda były kwestie terminologiczne dotyczące emanacji radowej. Już w 1899 r. Maria i Piotr Curie zauważyli, że ciała nieaktywne a znajdujące się w pobliżu preparatu radowego same stawały się promieniotwórcze. Uznali, że promieniotwórczość ta wywołana jest działaniem promieni Becquerela i nazwali ją promieniotwórczością wzbudzoną. $\mathrm{Na}$ początku XX w. badania Rutherforda i Fredericka Soddy'ego wykazały, że rad przekształca się samorzutnie w pierwiastek gazowy, nazywany emanacją radową, który także jest promieniotwórczy. To, co Maria i Piotr Curie uznali za wzbudzenie promieniotwórczości polegało w gruncie rzeczy na tym, że powstająca z radu emanacja gromadziła się na powierzchni znajdujących się w pobliżu przedmiotów. „Promieniotwórczość wzbudzona” była zatem niczym innym jak promieniotwórczością emanacji69.

Emanacja radowa miała istotne znaczenie zwłaszcza w medycynie w pierwszych dziesięcioleciach XX w. i Laboratorium Curie między innymi zajmowało się przygotowywaniem tej emanacji do celów medycznych. De facto emanacja radowa był to pierwiastek gazowy, który w tym czasie nie miał jeszcze ostatecznie ustalonej nazwy własnej.

Właśnie z takiej przesłanki wyszła Skłodowska-Curie, gdy zwróciła się do Rutherforda, ażeby unormować tą kwestię. W liście 11 stycznia 1919 r. napisała, że kilku uczonych zwróciło się do niej o nadanie emanacji jakiejś nazwy własnej. „Myślę, że byłoby to rzeczywiście bardzo praktyczne bowiem [określenie] «radowa emanacja» jest zbyt długie"70. Jednocześnie krytykowała propozycję określenia „niton”, wysuniętą swego czasu przez Williama Ramseya71. Pytała o sugestie Rutherforda. Pisała: „Jeśli Pana Laboratorium i moje

Rutherford and Boltwood. Letters on Radioactivity, s. 312-313.

Ibid., s. 314. William H. Bragg (1862-1942) - brytyjski fizyk, profesor uniwersytetów w Adelaide (Australia) i w Londynie, prezes Royal Society w latach 1935-1940, wraz z synem (Williamem L. Braggiem) prowadził badania struktury kryształów, wyzyskując dyfrakcję promieni rentgenowskich, za co w $1915 \mathrm{r}$. otrzymali Nagrodę Nobla. Arthur S. Eve (1862-1948) - brytyjski fizyk, pracujący w Kanadzie, od 1905 r. profesor na McGill University, współpracownik E. Rutherforda, od 1917 r. członek Royal Society.

67 J. Rowland, op. cit., s. 81.

68 B. Bensaude-Vincent, op. cit., s. 89.

69 J. Hurwic, op. cit., s. 55.

70 CUL, Add. 7653, C 111.

71 William Ramsay (1852-1916) - brytyjski fizyk, profesor uniwersytetów w Bristolu i Londynie, członek Royal 
zdecydowałoby się natychmiast na jakieś nazwy, można by oczekiwać, że zostałyby one zaakceptowane przez następny Kongres Radiologii"72. Proponowała następujące nazwy dla emanacji radu, toru i aktynu: „radionéon”, „thorionéon” i „actinéon”. Nazwy miały nawiązywać do „rodziny” pierwiastków promieniotwórczych (radu, toru i aktynu) oraz do gazów z „rodziny” neonu. Pisała, że za tymi nazwami opowiedzieli się m.in. Perrin i Langevin ${ }^{73}$.

Rutherford zaproponował krótsze nazwy („radion”, „thorion” i „actinion”), które Skłodowskiej-Curie z różnych względów nie odpowiadały (m.in. i z takiego, że "radion” może być mylony z „radium” ze względu na podobną fonetykę). Pisała: „Myślę, że możemy się zgodzić co do podjęcia decyzji. Jeśli jej nie podejmiemy, inni nadadzą nazwy takie jakie będą chcieli [...] i wtedy będzie dużo większy problem żeby je zmienić ${ }^{74}$.

W kolejnym liście do Rutherforda Skłodowska-Curie oponowała przeciw jego nowej propozycji - „radon”. Jej zdaniem, francuscy badacze bardzo by nie chcieli takiej nazwy bowiem wydaje się ona zbyt twarda i nie fonetyczna we francuskiej wymowie. Proponowała, żeby później jeszcze tę kwestię przedyskutować i może wysłać kwestionariusz do uczonych w tej sprawie ${ }^{75}$.

Wydaje się, że Rutherford nie zamierzał przeciągać sprawy i postanowił sam zadecydować. Na liście otrzymanym od Skłodowska-Curie dużymi literami napisał „name RADON" i oznaczenie „Rn"76.

I tak już pozostało. Jest to nazwa używana do dzisiejszego dnia ${ }^{77}$.

W tym czasie miały miejsce raczej sporadyczne kontakty kierowników obu laboratoriów, którzy (dość ostrożnie) wymieniali się informacjami na temat prowadzonych badań i używanych do nich przyrządów. ${ }^{78}$ W maju 1922 r. Rutherford odwiedził Paryż. Był bardzo zadowolony z tych odwiedzin i z możliwości ujrzenia Skłodowskiej-Curie, która z kolei pisała, że także dla niej było przyjemnością goszczenie Rutherforda przez kilka dni, że cieszy się jego zadowoleniem i poczuciem, że „życie znowu warte jest przeżycia” - jak napisał w swoim liście do niej ${ }^{79}$.

W 1923 r. miały miejsce w Paryżu uroczystości związane z 25-leciem odkrycia radu. Rutherford, mimo zaproszenia, nie przybył na to wydarzenie. Napisał, że w tym czasie będzie z rodziną na wakacjach we Włoszech. W swoim liście z tej okazji złożył kurtuazyjne, ale dość zdawkowe gratulacje, wymieniając jako autorów odkrycia najpierw Piotra, a dopiero na drugim miejscu Marię $e^{80}$. Z kolei Skłodowska-Curie wysłała Rutherfordowi sprawozdanie z przebiegu uroczystości, które on przeczytał „z dużym zainteresowaniem"81.

Society. Odkrył gazy szlachetne, zajmował się także promieniotwórczością (m.in. stwierdził, wraz z Soddym, że hel jest produktem rozpadu radu), w 1904 r. otrzymał Nagrodę Nobla.

81 Ibid., k. 350. List E. Rutherforda do M. Curie z 12.03.1926. 
W kolejnych latach oba laboratoria pozostawały ze sobą w stałym kontakcie. Rutherford prosił czasem Marię Sklodowską-Curie o zgodę na odwiedzenie jej laboratorium przez jego uczniów i współpracowników, informował ogólnie o swojej pracy ${ }^{82}$, a w 1929 r. zwrócił się bezpośrednio do ucznia Skłodowskiej-Curie Salomona Rosenbluma ${ }^{83}$.

Rosenblum prowadził badania w Laboratorium Curie od 1924 r., wykonując i publikując kilka prac wspólnie ze Skłodowską-Curie. W 1929 r. stał się odkrywcą tzw. subtelnej struktury promieni $\alpha$. Wyniki jego badań przyczyniły się do wyjaśnienia mechanizmu powstawania promieniowania $\gamma$ w czasie przemian jądrowych. Swoimi pracami z zakresu analizy magnetycznej promieniowania $\alpha$ rozpoczął w Laboratorium Curie nowy kierunek badań ${ }^{4}$.

Badania Rosenbluma wnosiły poważny wkład w wiedzę o jądrze atomowym. Nic więc dziwnego, że szczególnie zainteresowały Rutherforda. W liście z 10 czerwca 1929 r. pisał, że jest bardzo zainteresowany artykułem Rosenbluma z „Comptes Rendus” o subtelnej strukturze promieni $\alpha$ i że gratuluje mu rezultatów dotychczasowych badań. Prosił o ewentualne przysłanie zdjęć pokazujących przebieg zaobserwowanych przez Rosenbluma linii widma energetycznego promieni $\alpha$. Informował o specjalnym urządzeniu elektromagnetycznym pomocnym $w$ tego rodzaju badaniach ${ }^{85}$.

W tym czasie, a także wcześniej, w nauce o strukturze materii przodowało Laboratorium Rutherforda. To on i jego współpracownicy odkryli fazy przemiany promieniotwórczej, jądro atomowe i jego skład, a także dokonali wielu innych odkryć. We Francji natomiast w zakresie fizyki jądrowej prawie do końca lat dwudziestych panował pewien zastój. Skłodowska-Curie zajmowała się przede wszystkim badaniami radiochemicznymi, to jest chemią pierwiastków promieniotwórczych ${ }^{86}$. Nic więc dziwnego, że odkrycie Rosenbluma wywołało zupełnie spektakularny oddźwięk.

Rutherford podjął współpracę z Rosenblumem. W kwietniu 1932 r. donosił Skłodowskiej-Curie, że otrzymał od Rosenbluma wiadomości o ich wspólnych eksperymentach z emanacją aktynu i że wkrótce do niego napisze. Konstatował: „Całe zagadnienie dotyczące promieni $\alpha$ i $\gamma$ wyjaśnia się coraz bardziej i wkrótce powinniśmy wiedzieć więcej o tej skomplikowanej kwestii"87.

W tymże liście Rutherford zapytywał o zdrowie Skłodowskiej-Curie w związku z informacją o jej upadku w laboratorium i jego konsekwencjach. Wyrażał nadzieję na szybkie dojście do zdrowia i prosił o informacje na ten temat. Cały list utrzymany był w przyjacielskim tonie. Rutherford pisał o swoim domu, o wnukach, o tym że wrócił właśnie z wakacji w Walii, gdzie porządnie wypoczął, mimo brzydkiej pogody itd. Warto dodać, że był to trudny okres dla obojga Rutherfordów. Zmarła ich jedyna córka Eileen, osierocając czwórkę dzieci. Rutherford bardzo przeżył śmierć córki, ale w dalszym ciągu starał

82 Zob. np. listy Rutherforda z 12.03.1926 lub z 15.06.1926, BN, k. 350 i 351.

83 Salomon Rosenblum (1896-1959) - fizyk francuski, współpracownik Skłodowskiej-Curie. Odkrył subtelną strukturę widma energetycznego promieni $\alpha$.

84 Więcej na temat badań Rosenbluma zob. C.A. Pawłowski, Zdobycze naukowe Marii Skłodowskiej-Curie i nadane przez nią kierunki prac badawczych w Paryskim Instytucie Radowym, [w:] Wkład Marii Skłodowskiej-Curie do nauki. Szkice monograficzne, red. J. Hurwic, Warszawa 1954, s. 171-174.

85 BN NAF 18461, k. 352.

86 J. Hurwic, op. cit., s. 60 .

87 BN, k. 353, list z 16.04.1932. 
się intensywnie pracować. Wyrażał w liście zainteresowanie pracami Ireny, córki Skłodowskiej-Curie, „które otwierają bardzo interesujący kierunek badań, mogący pomóc w rozwoju naszej wiedzy na temat możliwości jądra atomowego". Wkrótce miała się odbyć dyskusja na ten temat i na temat nowych ustaleń w Royal Society, której Rutherford przewodniczył88.

Skłodowska-Curie odpowiedziała na ten list dopiero we wrześniu. Dziękowała za zainteresowanie jej stanem zdrowia. Wypadek w laboratorium spowodował załamanie jej kruchego zdrowia na wiele tygodni. Ale nie to bolało ją najbardziej, lecz fakt że musiała na ten czas przerwać swoje badania. Pisała: „Czułam się tak źle, że nawet nie miałam chęci odpowiadać wcześniej na Pana uprzejme listy. Jestem pewna, że Pan mi wybaczy". Odniosła się także do ostatnich wyników prac prowadzonych w Paryżu i Cambridge w zakresie fizyki nuklearnej i przypominała, że będą one tematem obrad na następnej Konferencji Solvaya. Wyrażała nadzieje, że zobaczy na niej Rutherforda, wspominała jego słowa o promieniotwórczości jako wspaniałym polu badawczym. Wyrażała zadowolenie z faktu, że młodzi ludzie kontynuują te badania. Wspomniała przy tym dwóch swych bardzo obiecujących uczniów, którzy zmarli w ostatnim czasie. W zakończeniu listu wyrażała zadowolenie z faktu, że Rutherford spędza wakacje z wnukami, napisała także o swoich wnukach - dzieciach Ireny - chłopcu i dziewczynce ${ }^{89}$.

Zdaniem biografa Rutherforda Skłodowska-Curie już po pierwszym spotkaniu była zauroczona postacią brytyjskiego uczonego, a następne lata tylko pogłębiły to zauroczenie i podziw dla jego naukowych osiągnięć ${ }^{90}$. Jak się wydaje, Rutherford także żywił coraz bardziej przyjazne uczucia względem Skłodowskiej-Curie, czego dawał dowody choćby w przytoczonej korespondencji. W opublikowanym w "Nature” wspomnieniu po śmierci Skłodowskiej-Curie pisał o swoim szacunku zarówno dla jej naukowych talentów, jak i dla jej wspaniałego charakteru oraz wybitnej osobowości ${ }^{91}$.

Otwarcie Konferencji Solvaya w 1933 r. w Brukseli nastąpiło uroczyście 23 października w auli Uniwersytetu. Paul Langevin, przemawiając, zaproponował, żeby w związku z otwarciem obrad wystosować telegram do króla Belgów, co też się stało. W treści telegramu wymieniając kraje, z których pochodzili uczestnicy (było ich 12), wymienił także Polskę, biorąc zapewne pod uwagę pochodzenie Skłodowskiej-Curie. Było to o tyle istotne, że zazwyczaj traktowano ją jako Francuzkę. W przemówieniu wspomniał także związanych z początkami Instytutu Paula Hégera i Hendrika Lorentza, a przede wszystkim samego Ernesta Solvaya, któremu właśnie wystawiono w Brukseli pomnik, a Langevin brał udział w jego odsłonięciu. Zaproponował, co zostało przyjęte, żeby wysłać telegramy z pozdrowieniami do nieobecnych na Konferencji członków komitetu naukowego: Charlesa-Eugène Guye'a i Alberta Einsteina. Dużo miejsca w przemówieniu poświęcił osobie tragicznie zmarłego przed miesiącem Paula Ehrenfesta - wybitnego fizyka i uczestnika Conseils de Physique w 1921 i 1927 r. Wskazał wreszcie na odmienny w porównaniu z dotychczasowymi konferencjami charakter zjazdu. Brali w nim bowiem udział nie tylko

88 Ibid.

89 Ibid., k. 354, list (kopia) z 12.09.1932. Wspomniane wnuki Marii Skłodowskiej-Curie to późniejsi znani fizycy jądrowi: Pierre Curie i Hélene Langevin.

90 I.Evans, Man of Power. The Life Story of Baron Rutherford of Nelson, London 1939, s. 228-230.

91 J. Rowland, op. cit., s. 141. 
teoretycy, ale i eksperymentatorzy. Zdaniem Langevina, należało przy ówczesnym stanie badań wspólnie skonfrontować dokonania jednych i drugich ${ }^{92}$.

Zagadnienia omawiane na Konferencji budziły wtedy ogromne zainteresowanie i były w tym czasie najżywiej dyskutowane w fizyce światowej. Wpływ na to miały wyniki niedawno przeprowadzonych eksperymentów. W 1932 r., w Cambridge, współpracownicy Rutherforda - John Cockroft ${ }^{93}$ i Ernest Walton ${ }^{94}$ - przeprowadzili pierwszą reakcję jądrową przy użyciu cząstek przyspieszonych w akceleratorze. Obaj byli pod wpływem pracy George'a Gamowa ${ }^{95}$, który udowodnił w 1928 r., że cząstka naładowana może wnikać do jądra atomu w wyniku efektu tunelowego, nawet jeśli ma energię mniejszą od bariery wynikającej z odpychania przez dodatni ładunek jądra. W tymże 1932 r. James Chadwick ${ }^{96}$ odkrył neutron, zainspirowany artykułem Ireny i Frédérica Joliot-Curie opublikowanym na początku tego roku. Wszyscy ci uczeni, a także nobliści z 1932 i 1933 r. - Werner Heisenberg ${ }^{97}$ i Paul Dirac - wygłosili na Konferencji referaty o rezultatach ostatnio prowadzonych badań.

Konferencja Solveya w Brukseli w 1933 r. była pewnym podsumowaniem osiągnięć obu laboratoriów: Marii Sklodowskiej-Curie i Ernesta Rutherforda oraz własnych dokonań ich kierowników. Obydwoje dobiegali kresu swoich dni. Maria zmarła w 1934 r., Rutherford w 1937. Z pewnością ośrodek angielski i sam Rutherford mieli większe i spektakularne osiągnięcia, ale laboratorium paryskie także mogło pochwalić się wieloma sukcesami, z ostatnim przed śmiercią Marii - odkryciem w 1934 r. sztucznej promieniotwórczości przez Irenę i Frédérica Joliot Curie, za co w 1935 r. oboje otrzymali Nagrodę Nobla z chemii.

Można oczywiście powiedzieć, że w tej naukowej rywalizacji między obydwoma laboratoriami zwyciężył Rutherford i jego szkoła, ale we współpracy (chociaż skromnej), która jest ważniejsza dla rozwoju nauki, zwycięstwo było wspólne i należało do obojga uczonych.

\section{Bibliografia}

\section{Źródła archiwalne}

Bibliothéque Nationale (BN), NAF 18461, Korespondencja Marii Skłodowskiej-Curie Cambridge University Library (CUL), Add 7653, Korespondencja Ernesta Rutherforda

92 Institut International de Physique Solvay. Statuts [w:] Structure et propriétés des noyaux atomiques. Rapports et discussions du septieme Conseil de Physique tenu a Bruxelles du 22 au 29 octobre 1933 sous les auspices de I'Institut International de Physique Solvay, Paris 1934, s. VI-X. Zob. także J. Piskurewicz, op. cit., s. 22-24.

93 John Cockroft (1897-1967) - brytyjski fizyk, w latach 1939-46 profesor uniwersytetu w Cambridge, dyrektor Brytyjskiego Instytutu Badań Jądrowych, za pionierskie prace, zwłaszcza za wspomniane przeprowadzenie z Waltonem pierwszej reakcji jądrowej przy użyciu cząstek przyspieszonych w akceleratorze, otrzymał w 1951 r. Nagrodę Nobla.

94 Ernest Walton (1903-1995) - fizyk irlandzki, od 1946 r. profesor uniwersytetu w Dublinie, za pionierskie prace, zwłaszcza za wspomniane przeprowadzenie z Cockroftem pierwszej reakcji jądrowej przy użyciu cząstek przyspieszonych w akceleratorze, otrzymał w 1951 r. Nagrodę Nobla.

95 George Gamow (1904-1968) - amerykański fizyk pochodzenia rosyjskiego, w latach 1934-68 profesor uniwersytetu w Waszyngtonie. Prowadził badania dotyczące głównie fizyki jądrowej i astrofizyki.

96 James Chadwick (1891-1974) - brytyjski fizyk, profesor uniwersytetów w Liverpool, Manchesterze i Cambridge. W 1932 r. odkrył neutron i określił w przybliżeniu jego masę, za co w 1935 r. otrzymał Nagrodę Nobla. W okresie II wojny światowej brał udział w projekcie budowy bomby atomowej.

97 Werner Heisenberg (1901-1976) - niemiecki fizyk teoretyk, od 1927 r. profesor uniwersytetu w Lipsku, od 1941 r. w Berlinie. Współtwórca mechaniki kwantowej. Za stworzenie podstaw mechaniki kwantowej otrzymał w 1932 r. Nagrodę Nobla. 


\section{Źródła drukowane}

Blanc K., Marie Curie et le Nobel, Uppsala 1999.

La structure de la matière. Rapports et discussions du Conseil de Physique tenu a Bruxelles du 27 au 31 octobre 1913 sous les auspices de I'Institut International de Physique Solvay, Paris 1921.

La théorie du rayonnement et les quanta. Rapports et discussions, Paris 1912.

Mehra J., The Solvay Conferences on Physics: Aspects of the Development of Physics since 1911, Boston 1975.

Rutherford E., The Collected Papers of Lord Rutherford of Nelson, t. 1-2, London 1962-1963.

Rutherford and Boltwood. Letters on Radioactivity, red. L. Badash, New Haven, London 1969.

Skłodowska-Curie M., Autobiografia, Warszawa 2004.

Structure et propriétés des noyaux atomiques. Rapports et discussions du septieme Conseil de Physique tenu a Bruxelles du 22 au 29 octobre 1933 sous les auspices de I'Institut International de Physique Solvay, Paris 1934.

\section{Literatura przedmiotu}

Bensaude-Vincent B., Langevin 1872-1946. Science et Vigilance, Paris 1987.

Evans I., Man of Power. The Life Story of Baron Rutherford of Nelson, London 1939.

Hurwic J., Maria Skłodowska-Curie i promieniotwórczość, Warszawa 2001.

Pawłowski C.A. Zdobycze naukowe Marii Skłodowskiej-Curie i nadane przez nią kierunki prac badawczych w Paryskim Instytucie Radowym, [w:] Wkład Marii Skłodowskiej-Curie do nauki. Szkice monograficzne, red. J. Hurwic, Warszawa 1954.

Piskurewicz J., Zakochana w fizyce. Udział i rola Marii Skłodowskiej-Curie w organizacji i pracach konferencji Solvaya, „Analecta” 2017, nr 1.

Rowland J., Ernest Rutherford Atom Pioneer, New York 1957.

Quinn S., Życie Marii Curie, Warszawa 1997.

Starosielska-Nikitina O., Starosielska H., Rola Marii Skłodowskiej-Curie w rozwoju fizyki jądrowej [w:] Studia poświęcone Marii Skłodowskiej-Curie i Marianowi Smoluchowskiemu, Wrocław 1968.

Wróblewski A.K., Historia fizyki, Warszawa 2006.

prof. dr hab. Jan Piskurewicz, profesor w Instytucie Historii Nauki PAN. Ostatnie książki: Z ziemi włoskiej dla Polski. Artur Wołyński i jego działalność w Italii w drugiej połowie XIX wieku (2012) oraz Między nauką a polityką. Maria Skłodowska Curie w laboratorium i w Lidze Narodów (2007).

e-mail: jan.piskurewicz@wp.pl

Data zgłoszenia artykułu: 23 kwietnia 2019

Data przyjęcia do druku: 3 czerwca 2019 